Економічні науки: збірник наукових прачь Луиького національного технічного університету. Серія “Регіональна економіка". Випуск 18 (71). Редкол.: відп. ред. д.е.н., професор Л.Л. Ковальська. Луцьк: ІВВ Луиького НТУ, 2021. 278 с.

3. Zhydkov S.A. Sostoianye y perspektyvы razvytyia myrovoho runka prodovolstvennoho zerna. Vestnyk Mychurynskoho hosudarstvennoho ahrarnoho unyversyteta. 2019. №1. S. 154-156

4. URL: http://magazine.faaf.org.ua/suchasniy-stan-ta-osoblivosti-rinkivzerna-v-ukraini-ta-kanadi.html

5. Kyrylenko I.H., Ivchenko V.Ye., Demianchuk V.V. Main trends in the development of the world food market and production in Ukraine. Mezhdunarodnыi nauchno- proyzvodstvennыi zhurnal «Эkonomyka APK». 2018. № 9(287). S. 34-45.

6. Surenkova V.A. Zarubezhnыі орыt proyzvodstva zerna. Colloquiumjournal. 2019. №16-9 (40). S. 19-21.

DOI: https://doi.org/10.36910/2707-6296-2021-18(71)-6

УДК 339.176.004

Зубко Т.Л., к.е.н., доцент

Київський національний

торговельно-економічний

університет

\title{
ІНСТРУМЕНТИ ІННОВАЦІЙНОГО РОЗВИТКУ ТОРГОВЕЛЬНОГО ПІДПРИЄМСТВА
}

Торгівля розвивається швидкими темпами як у світі, так і в Україні, що пов 'язано не тільки з інвестиціями, але й з інноваціями. Тому вивчення та узагальнення досвіду їх застосування $\epsilon$ актуальним. У статті розглянуто теоретичні положення та практичний інструментарій залучення інновацій на торговельних підприємствах. Розглянуто види інновацій та відповідні їм стратегії. В статті також досліджено особливості інноваційної діяльності торгівельних підприємств. Удосконалено класифікацію базових інноваційних стратегій, які формуються залежно від положення організації на ринку та значущості інноваційного потенціалу.

Ключові слова: інноваційний розвиток, інструменти, торгівля, підприємства, євроінтеграція.

Zubko T.

\section{TOOLS OF INNOVATIVE DEVELOPMENT OF A TRADE ENTERPRISE}

Globalization processes in the world have stimulated the development of international trade, and accordingly, this area needs to find and justify ways to 
Економічні науки: збірник наукових праць Луцького національного технічного університету. Серія "Регіональна економіка". Випуск 18 (71). Редкол.: відп. ред. д.е.н., професор Л.Л. Ковальська. Луиььк: ІВВ Луцьького НТУ, 2021. 278 с.

innovate. Innovation is becoming an integral part of the activities of trade enterprises, which determines the relevance of the study.

Analysis of the evolution of scientific thought shows that the concept of innovation activity in the literature more often applies to enterprises. These works are mostly devoted to methods of assessing and increasing the innovative potential of enterprises. Many Ukrainian scientists study the problems and prospects of retail trade development (in particular, innovation), but the issue of defining tools for innovative development of enterprises remains unresolved.

The purpose of the article is to expand the theoretical knowledge on the introduction of innovations in the activities of commercial enterprises, study and generalize the features of innovative activities in the field of trade of Ukraine.

The processes of globalization and European integration have a significant impact on the economic development and economic security of Ukraine. These processes make new demands on the Ukrainian economy to reform it, to abandon the "raw material" direction and the transition to an "intellectual economy." All this determines the focus of economic processes on the use of intellectual potential and growth of innovation activity.

The article considers the theoretical provisions and practical tools for attracting innovation in commercial enterprises.

According to the scope of innovation in trade can be divided into several groups: improving the trade and technological process, improving the organizational and management process, product innovation and the involvement of templates.

Types of innovations and corresponding strategies are considered. The following types of innovations are most often used: product, technological, innovations in positioning.

The article also examines the features of innovative activities of trade enterprises. The classification of basic innovation strategies, which are formed depending on the organization's position in the market and the significance of innovation potential, has been improved.

Among the promising areas for strengthening the innovation of trade can be identified: new technologies that open up additional opportunities for differentiation of strategies; information and communication technologies for the study and accounting and evaluation of client values; information technologies, including the Internet, which allow to interact with the client anywhere and at any time, carry out the promotion of goods, sales promotion in the trading business through the creation of a modern online trading system

Analysis of trade development makes it possible to identify innovative priorities for Ukraine, namely: active development of e-commerce; introduction into practice of flexible electronic pricing, electronic means of support and bar coding of goods, means of radio frequency technology for monitoring the movements of visitors; use of innovative solutions for the transition to personalized customer accounting through the introduction of club, discount and self-service cards; complex automation of all business processes of modern retail trade; development of format and product innovations, which are aimed at reducing the time of buyers and providing them with environmentally friendly and high-quality goods and services. 
Економічні науки: збірник наукових праџь Луцького національного технічного університету. Серія “Регіональна економіка". Випуск 18 (71). Редкол.: відп. ред. д.е.н., професор Л.Л. Ковальська. Луиьк: ІВВ Луиького НТУ, 2021. 278 с.

Key words: innovative development, tools, trade, enterprises, European integration.

Зубко Т.Л.

\section{ИНСТРУМЕНТЫ ИННОВАЦИОННОГО РАЗВИТИЯ ТОРГОВОГО ПРЕДПРИЯТИЯ}

Торговля развивается быстрыми темпами как в мире, так и в Украине, что связано не только с инвестициями, но и с инновациями. Поэтому изучение и обобщение опыта их применения актуально. В статье рассмотрены теоретические положения и практический инструментарий для внедрения инноваций на торговых предприятиях. Рассмотрены виды инноваций и соответствующие им стратегии. В статье также исследованы особенности инновационной деятельности торговых предприятий. Усовершенствована классификация базовых инновационных стратегий, которые формируются в зависимости от положения организации на рынке и значимости инновационного потенциала.

Ключевые слова: инновационное развитие, инструменты, торговля, предприятия, евроинтеграция.

\section{Постановка проблеми у загальному вигляді та її зв'язок 3} важливими науковими та практичними завданнями. Глобалізаційні процеси у світі стимулювали розвиток міжнародної торгівлі, і відповідно, ця сфера потребує пошуку й обгрунтування шляхів впровадження інновацій. Інновації стають невід'ємною складовою діяльності підприємств торгівлі, що і обумовлює актуальність дослідження.

Аналіз останніх досліджень, у яких започатковано вирішення проблеми. Аналіз еволюції наукової думки (Є. Галушко (1999), Ю. Слепец, А. Костенко (2001), Р. Ісаксон, П. Йохансон, К. Фіщер (2010), О. Богма (2011), Н. Гіл, М. Мiоззо, С. Масіні (2012), В. Головатюк (2012), М. Рижков (2014), В. Нижник (2018), Е. Ронді, А.Де Массіс, Дж. Котлер (2019) та інших) свідчить, що поняття інноваційної активності в літературі частіше стосується підприємств [1-9]. Їх праці здебільшого присвячено методам оцінки та збільшення інноваційного потенціалу підприємств. Вивченням проблем i перспектив розвитку роздрібної торгівлі (зокрема, 
Економічні науки: збірник наукових праџь Луцького національного технічного університету. Серія “Регіональна економіка". Випуск 18 (71). Редкол.: відп. ред. д.е.н., професор Л.Л. Ковальська. Луиьк: ІВВ Луиького НТУ, 2021. 278 с.

інноваційного) займається багато українських учених: А. Мазаракі [10], Т. Мельник [10], Г. П'ятницька [11] та інші.

Метою статті $\epsilon$ розширення теоретичних знань 3 впровадження інновацій у діяльність торговельних підприємств, вивчення та узагальнення особливостей інноваційної діяльності сфери торгівлі України.

Виклад основного матеріалу дослідження 3 повним обгрунтуванням отриманих наукових результатів. На підприємстві зазвичай об єктами інноваційної діяльності є: засоби виробництва і технологічні процеси, вироблена (або закуплена продукція) i iï якість, кадровий потенціал, організаційний розвиток (управлінський потенціал), соціальна сфера та ін. Суб єктами інноваційної діяльності на підприємстві виступають об єднання людей, які спільно здійснюють розробку та впровадження нововведень $[8,12]$.

В теорії управління інноваційними проєктами існує підхід, що інноваційна активність - один $з$ проявів трудової активності персоналу, реалізацією їх творчих здібностей, набутих знань, професіоналізму незалежно від сфери діяльності. За іншим підходом науковці М. Вороновська [13], С. Мочерний [14] вважають, що інноваційна діяльність стосується виключно персоналу i, відповідно, інноваційна активність персоналу - це цілеспрямована діяльність суб єктів підприємницької діяльності для конструювання, створення i освоєння якісно нових продуктів, об єктів інтелектуальної власності, впровадження більш досконалих технологій, форм організації і управління виробництвом [14, с. 655].

Вагомий вплив на економічний розвиток та економічну безпеку України мають процеси глобалізації та євроінтеграції. Ці процеси висувають перед українською економікою нові вимоги до iii реформування, відмови від «сировинного» спрямування і перехід до «інтелектуальної економіки». Це все зумовлює орієнтацію економічних процесів на використання інтелектуального потенціалу i зростання інноваційної активності. В «Стратегії інноваційного розвитку України на 2010-2020 pp. в умовах глобалізаційних викликів» 
Економічні науки: збірник наукових прачь Луиького національного технічного університету. Серія "Регіональна економіка". Випуск 18 (71). Редкол.: відп. ред. д.е.н., професор Л.Л. Ковальська. Луцьк: ІВВ Луцького НТУ, 2021. 278 с.

зазначається, що зростаюча залежність національної економіки від зовнішніх факторів, обмеженість і висока вартість енергетичних ресурсів, обмеженість ресурсної бази, мають слугувати стимулом для використання інновацій 3 метою забезпечення сталого економічного розвитку в цілому [15].

Існують різні види інновацій. На думку колективу авторів [16] для підприємств найчастіше використовуються такі види інновацій: продуктові, технологічні, інновації в позиціонуванні. Усі ці стратегії можуть використовуватися одночасно.

Найпоширенішою інноваційною стратегією є продуктові інновації, тобто зміна продуктів та/або послуг. Зростання конкуренції, зміни потреб і переваг клієнтів, розвиток технологій, зміни законодавства та скорочення життєвих циклів продукції змушують підприємства своєчасно на це реагувати, підвищуючи якість продукції, змінюючи дизайн виробів, тару.

Технологічні інновації визначаються як зміни у способах створення та доставки продукції i послуг. Також до технологічних інновацій належать такі, що полягають у впровадженні нових процесів для підвищення якості продукції, коли підприємства використовують менше традиційних та більше екологічно чистих технологій. Такі інновації дозволяють бренду забезпечити підвищення іміджу. При цьому клієнти купують продукцію обраного бренду, суспільство отримує вигоду від енергозбереження та зменшення відходів. За даними Держкомстату з 20,2\% українських підприємств, що втілювали інновації у 2020 році, лише $12 \%$ пов язані 3 виробами, 2\% - 3 видами матеріалів, і лише 8,9\% - 3 новими технологіями. Інноваційні теоретичні розробки у 2019 році склали близько 18\%, але спостерігається тенденція купівлі закордонними компаніями цих розробок. У 2020 році ситуація практично не покращилась і рівень інновацій склав $18,1 \%$. Витрати на інновації в нашій країні, порівняно 3 країнами Європейського Союзу, незначні.

Інновації в позиціонуванні зосереджені на змінах способу, яким клієнти сприймають або дізнаються про продукцію та/або послуги. За даними Держкомстату із 
Економічні науки: збірник наукових праџь Луцького національного технічного університету. Серія "Регіональна економіка". Випуск 18 (71). Редкол.: відп. ред. д.е.н., професор Л.Л. Ковальська. Луиьк: ІВВ Луцького НТУ, 2021. 278 с.

загальної кількості підприємств, що мали доступ до мережі інтернет, використовували електронні торгівлю (у 2018 р.-5\%, у 2019 р. - 4,8\%, у 2020 р. - 4,9\%), веб-сайт з мультимедійним вмістом (у 2019 р. - 12\%, у 2020 р. - 12,5\%), засоби обміну знаннями (у 2018 р. - 18,\%, у 2019 р. - 18,3\%, у 2020 р. $18,9 \%$ ). Завдяки розвитку каналів комунікацій та інформаційних технологій у підприємств з`яляється можливість в повному обсязі використовувати свої і «чужі» нематеріальні активи, а саме інформацію та знання.

Інноваційний розвиток сфери торгівлі вивчається науковцями нашої та інших країн. Так, Л. Федулова, К. Пугачевська, розглядали вплив інновацій саме в роздрібній торгівлі $[17,18]$. Інновації в торгівлі можна поділити на кілька груп за сферою використання (табл. 1).

Таблиця 1

Особливості інноваційної діяльності сфери торгівлі України

\begin{tabular}{|c|c|}
\hline Ознака та характеристика & Приклади використання \\
\hline $\begin{array}{l}\text { Удосконалення торгово- } \\
\text { технологічного процесу. } \\
\text { Нові технології продажів: } \\
\text { FRID -технології, } \\
\text { електронні цінники, } \\
\text { енергозберігаючі } \\
\text { технології, SAP-технології, } \\
\text { штрихтехнології }\end{array}$ & $\begin{array}{l}\text { FOZZY розвивають власне виробництво, } \\
\text { започаткували власні марки на кшталт } \\
\text { «Премія», «Повна чаша», «Зелена } \\
\text { країна», «РROTEX». Також FOZZY } \\
\text { впровадили роздрібне пакування «на } \\
\text { місцяХ», що є спрощенням логістичного } \\
\text { ланцюга. }\end{array}$ \\
\hline $\begin{array}{l}\text { Удосконалення } \\
\text { організаційно- } \\
\text { управлінського } \\
\text { процесу. } \\
\text { Спрощення докумен- } \\
\text { тообігу та системи збуту. } \\
\text { Залучення маркетплейсів }\end{array}$ & $\begin{array}{l}\text { Багато ритейлерів (АШАН, FOZZY-груп, } \\
\text { EVA, Еpicentr та ін.) створили власні } \\
\text { iнтернет-магазини, Перевагами цього є } \\
\text { зменшення ціни товарів, безготівкова } \\
\text { сплата, і відповідно збільшення кількості } \\
\text { покупців та покупок. Запровадження } \\
\text { системи дисконтних карток. }\end{array}$ \\
\hline $\begin{array}{l}\text { Продуктові інновації. } \\
\text { Просування новинок }\end{array}$ & $\begin{array}{l}\text { AШАН, FOZZY груп, METRO проводять } \\
\text { ознайомлюючі презентації нової } \\
\text { продукції, впроваджують початкову } \\
\text { льготну ціну, а надалі, при завоюванні } \\
\text { певної позиції, ціну «підтягують» до } \\
\text { рівня аналогів }\end{array}$ \\
\hline
\end{tabular}


Економічні науки: збірник наукових праџь Луцького національного технічного університету. Серія “Регіональна економіка". Випуск 18 (71). Редкол.: відп. ред. д.е.н., професор Л.Л. Ковальська. Луцьк: ІВВ Луиького НТУ, 2021. 278 с.

Продовження таблиці 1

\section{Залучення темплейтів.} Впровадження засобів діджиталізації в торгівлі

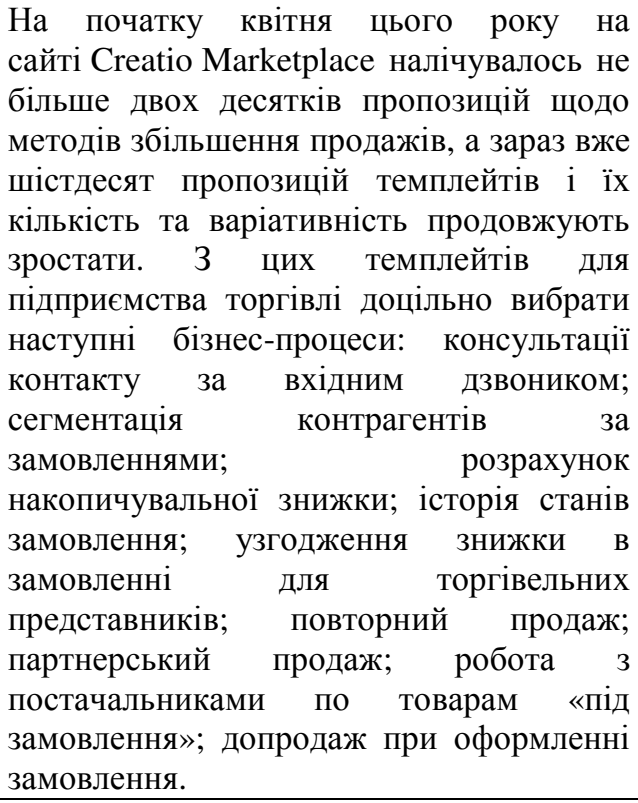

Джерело: складено автором за [16-20]

Серед перспективних напрямків посилення інноваційності сфери торгівлі можна виокремити: нові технології, що дозволяють відкрити додаткові можливості диференціації стратегій; інформаційно-комунікаційні технології для вивчення й обліку та оцінки цінностей клієнта; інформаційні технології, у т.ч., Інтернет, що дають змогу взаємодіяти з клієнтом у будьякому місці й у будь-який час, здійснюють просування товарів, стимулювання збуту в торговельному бізнесі завдяки створенню сучасної системи онлайн-торгівлі [17].

Для будь-якого сучасного підприємства інноваційна діяльність стає пріоритетом його розвитку. При цьому виникає потреба у розробці інноваційної стратегії.

На цей час існують базові інноваційні стратегії, які формуються залежно від положення фірми на ринку та значущості інноваційного потенціалу (табл. 2). 
Таблиця 2

Класифікація інноваційних стратегій

\begin{tabular}{|c|c|c|c|}
\hline Назва стратегії & Характеристика & Можливі недоліки & Можливі загрози \\
\hline Імітаційна & $\begin{array}{l}\text { Запозичення технологій на стороні або придбання } \\
\text { ліцензій на результати дослідження і розробок }\end{array}$ & $\begin{array}{l}\text { Потреба у значних } \\
\text { коштах }\end{array}$ & $\begin{array}{l}\text { Нестача персоналу для } \\
\text { впровадження інновацій }\end{array}$ \\
\hline Ковзання & $\begin{array}{l}\text { Підприємство має середній потенціал і виводить на } \\
\text { ринок продукцію тільки після того, як сильніший } \\
\text { конкурент її випробує }\end{array}$ & $\begin{array}{l}\text { Характер цієї стратегії } \\
\text { наслідуючий, відповідно } \\
\text { підприємство отримує } \\
\text { менший прибуток ніж } \\
\text { лідер }\end{array}$ & $\begin{array}{l}\text { Постійне «відставання» } \\
\text { від лідера знижує рівень } \\
\text { конкурентоспроможності } \\
\text { та економічної безпеки } \\
\text { підприємства }\end{array}$ \\
\hline Переваги & $\begin{array}{l}\text { Передбачається тісний зв'язок підприємства зі } \\
\text { світовими досягненнями науки та технології, } \\
\text { причому продукція (послуги) користується } \\
\text { максимальним попитом. Як правило, таке } \\
\text { підприємство - лідер у своєму сегменті, } \\
\text { підприємство є першим при впровадженні } \\
\text { нововведення на певному сегменті ринку }\end{array}$ & $\begin{array}{l}\text { Концентрація значних } \\
\text { коштів для інновацій }\end{array}$ & $\begin{array}{l}\text { Можливе неефективне } \\
\text { використання коштів, } \\
\text { загрози з боку персоналу }\end{array}$ \\
\hline $\begin{array}{l}\text { Максимального } \\
\text { випередження }\end{array}$ & $\begin{array}{l}\text { Перехід до технологій, організаційного устрою, } \\
\text { вищим за середній в галузі, передбачає власні } \\
\text { дослідження }\end{array}$ & $\begin{array}{l}\text { Більші часові та } \\
\text { матеріальні витрати }\end{array}$ & $\begin{array}{l}\text { Нестача коштів та часу } \\
\text { для впровадження, } \\
\text { небезпека хибних } \\
\text { менеджерських рішень }\end{array}$ \\
\hline Відтворення & $\begin{array}{l}\text { Застосовується для застарілих у сенсі нововведень } \\
\text { продукції (послуг), які ще мають попит. Інновації } \\
\text { спрямовуються на вдосконалення процесів } \\
\text { виготовлення та збуту. Продукція реалізується на } \\
\text { стабільному ринку і більша їі частка знаходиться у } \\
\text { стадії зрілості }\end{array}$ & $\begin{array}{l}\text { Потребує постійного } \\
\text { моніторингу структури } \\
\text { товарообігу та } \\
\text { відповідно швидкого } \\
\text { реагування на зміни }\end{array}$ & $\begin{array}{l}\text { Нестача коштів для усіх } \\
\text { видів продукції (послуг), } \\
\text { що потребують } \\
\text { вдосконалення. Ризик } \\
\text { зниження попиту }\end{array}$ \\
\hline Якості & $\begin{array}{l}\text { Характерна спрямованість на інноваційну } \\
\text { діяльність, пов язану із зростанням якості товарів } \\
\text { (послуг), які користуються попитом }\end{array}$ & $\begin{array}{l}\text { Потребує постійного } \\
\text { оновлення та } \\
\text { удосконалення системи } \\
\text { вимог якості }\end{array}$ & $\begin{array}{l}\text { Ризик зниження попиту } \\
\text { внаслідок насичення } \\
\text { ринку або виникнення } \\
\text { потреб у інших товарах }\end{array}$ \\
\hline
\end{tabular}


Продовження таблиці 2

\begin{tabular}{|c|c|c|c|}
\hline Назва стратегії & Характеристика & Можливі недоліки & Можливі загрози \\
\hline $\begin{array}{l}\text { «Зручного } \\
\text { випадку» або } \\
\text { «Ніші» }\end{array}$ & $\begin{array}{l}\text { Полягає у незначному та маловитратному удосконаленні } \\
\text { товару (послуги). Фактично це швидка реакція } \\
\text { підприємства на сигнали зовнішнього середовища та } \\
\text { своєчасне виявлення ринкових можливостей, які } \\
\text { 3`являються за нових обставин. При цьому підприємство є } \\
\text { майже єдиним на ринку, що випереджає конкурентів. }\end{array}$ & $\begin{array}{l}\text { Потребує висококваліфікованого } \\
\text { персоналу, розробки системи } \\
\text { управління якістю }\end{array}$ & $\begin{array}{l}\text { Можливе негативне } \\
\text { сприйняття продукції } \\
\text { цільовими групами } \\
\text { споживачів }\end{array}$ \\
\hline Опозиції (захисту) & $\begin{array}{l}\text { Застосовується для протистояння конкурентам. } \\
\text { Характерним є колаборація підприємств для підвищення } \\
\text { конкурентоспроможності за допомогою випуску нової } \\
\text { продукції (послуг) чи нових технологій. Як правило, } \\
\text { вносяться істотні поліпшення, що дозволяє } \\
\text { використовувати новації в інших сферах або ринках. } \\
\text { Головне - оптимізувати співвідношення витрати-випуск. }\end{array}$ & $\begin{array}{l}\text { Потребує значних зусиль у науково- } \\
\text { дослідницькій сфері. Підприємство } \\
\text { змушене приділяти багато уваги } \\
\text { навчанню персоналу та рекламі і } \\
\text { просуванню на ринок продукції шляхом } \\
\text { розгалуженого сервісу та технічного } \\
\text { обслуговування. }\end{array}$ & $\begin{array}{l}\text { Нестача коштів на } \\
\text { НДДКР. Зміна попиту } \\
\text { споживачів внаслідок } \\
\text { змін уподобань завдяки } \\
\text { конкурентам. Зниження } \\
\text { платоспроможності } \\
\text { населення. }\end{array}$ \\
\hline $\begin{array}{l}\text { Виробничої } \\
\text { замінності }\end{array}$ & $\begin{array}{l}\text { Використовується, якщо підприємство виготовляє не } \\
\text { менше } 50 \% \text { технологічно подібної між собою продукції. }\end{array}$ & $\begin{array}{l}\text { Продукція підприємства досить } \\
\text { однотипна, відповідно попит не зростає }\end{array}$ & $\begin{array}{l}\text { Загроза зниження попиту, } \\
\text { загроза несприйняття } \\
\text { новим ринком «відносно } \\
\text { старої продукції» }\end{array}$ \\
\hline Відкриття & Конкурентні переваги новації незаперечні & $\begin{array}{l}\text { Ця стратегія потребує великих } \\
\text { грошових витрат і } є \text { ризикованою }\end{array}$ & $\begin{array}{l}\text { Несприйняття новації } \\
\text { покупцями. Ризик } \\
\text { неплатоспроможності } \\
\text { населення. Ризик } \\
\text { банкрутства. }\end{array}$ \\
\hline Відстоювання & Фактично це спроба зберегти свій сегмент ринку. & $\begin{array}{l}\text { Ця стратегія не може бути } \\
\text { використана в довгостроковій } \\
\text { перспективі. Підприємство, як } \\
\text { правило, не має матеріальних та } \\
\text { інтелектуальних засобів для } \\
\text { відновлення продукції. }\end{array}$ & $\begin{array}{l}\text { Загроза зниження } \\
\text { конкурентоспроможності } \\
\text { внаслідок розвитку } \\
\text { конкурентів; можливість } \\
\text { нестачі коштів для } \\
\text { розвитку }\end{array}$ \\
\hline
\end{tabular}


Економічні науки: збірник наукових праць Луцького начіонального технічного університету. Серія "Регіональна економіка". Випуск 18 (71). Редкол.: відп. ред. д.е.н., професор Л.Л. Ковальська. Луиьк: ІВВ Луиького НТУ, 2021. 278 с.

Для вибору оптимальної стратегії розвитку підприємства на основі інноваційних інструментів необхідно спершу розрахувати значення його інноваційного потенціалу, зважити на показані в таблиці характеристики, можливі недоліки та загрози.

Основою стратегічного управління є вибір стратегії підприємства, тобто плану дій, спрямованого на посилення його позицій, задоволення споживачів та збільшення прибутку. Вибір конкретної стратегії означає, що із усіх можливих варіантів розвитку необхідно вибрати один, у відповідності 3 яким і буде розвиватися підприємство. Напрямки руху, етапи i дії, спрямовані на досягнення необхідних результатів, називають стратегічним планом підприємства.

Стратегія розвитку підприємства може бути визначена як довгостроковий план, який містить комплекс рішень щодо вибору напрямку його розвитку, визначення його основних цілей, а також моделі дій щодо формування та ефективного використання потенціалу i дає можливість створення сприятливих внутрішніх та зовнішніх умов для успішного подолання основних стадій розвитку.

Висновки. Аналіз розвитку торгівлі дає можливість визначити інноваційні пріоритети для України, а саме: активний розвиток електронної торгівлі; впровадження в практику роботи гнучкого електронного ціноутворення, електронних засобів супроводу i штрихового кодування товарів, засобів радіочастотної технології моніторингу рухів відвідувачів; використання інноваційних рішень для переходу до персоніфікованого обліку покупців за рахунок впровадження клубних, дисконтних і карток самообслуговування; комплексна автоматизація усіх бізнес-процесів сучасної роздрібної торгівлі; розробка форматних та товарних новацій, які спрямовані на скорочення часу покупців i надання їм екологічно чистих i якісних для споживання товарів та послуг.

\section{Список бібліографічного опису}

1. Галушко Є.С. Підвищення ефективності використання інноваційного потенціалу в умовах переходу до ринкових відносин: автореф. дис. ... канд. екон. наук: 08.06.02. Донецьк. 1999. 23 с. 
Економічні науки: збірник наукових праць Луцького начіонального технічного університету. Серія "Регіональна економіка". Випуск 18 (71). Редкол.: відп. ред. д.е.н., професор Л.Л. Ковальська. Луцьк: ІВВ Луцького НТУ, 2021. 278 с.

2. Слепец Ю.С., Костенко А.П. Инновационный потенциал как экономическая категория. Збірник наук. прац̧ь НТУ «ХПІ». Харків. 2001. Вип.24. С. 93-101.

3. Isaksson R., Johansson P., Fischer K. Detecting Supply Chain Innovation Potential for Sustainable Development. Journal of Business Ethics (2010) 97:425-442 Springer, 2010. URL: https://www.divaportal.org/smash/get/diva2:979822/FULL TEXT01.pdf DOI 10.1007/s10551010-0516-z

4. Богма О.С. Сутність інноваційного потенціалу підприємства. Вісник Запорізького національного університету. 2011. №1(9). С. 12-15.

5. Gil N., Miozzo M., Massini S. The innovation potential of new infrastructure development: An empirical study of Heathrow airport's T5 project. Research Policy 41 (2012) 452-466. URL: https://personalpages.manchester.ac.uk/ staff/nuno.gil/Journal\%20articles/RESPOL\%20Innovation\%20Potential.pdf

6. Головатюк В.М. Інвестиційна привабливість інноваційної сфери економіки України / за наук. ред. В.П. Соловйова. Київ: Фенікс, 2012. 364 с.

7. Рижков М.М., Макаренко Є.А., Піскорська Г.А. Інноваційний потенціал України в міжнародних відносинах: монографія. Київ: Центр вільної преси, 2014. 283 с.

8. Нижник В.M. Інноваційне управління промисловими підприємствами в системі ефективного використання конкурентного потенціалу: монографія / за наук. ред. В.М. Нижника. Хмельницький: ХНУ, 2014. 547 c.

9. Rondi E., De Massis A., Kotlar J. Unlocking innovation potential: A typology of family business innovation postures and the critical role of the family system. Journal of Family Business Strategy, 10(4), 1-13. 2019. URL: https://re.public.polimi.it/retrieve/handle/11311/1069328/478958/Rondi\%20et\%20al ._Family\%20business\%20innovation\%20postures_Post-print.pdf

10. Мазаракі А., Мельник Т. Інновації як джерело стратегічних конкурентних переваг. Вісник КНТЕУ. 2010. № 2. С. 5-17.

11. П'ятницька Г.Т., П'ятницька, Н.О. Вплив інноваційних змін на діяльність підприємств ресторанного господарства. Економіка розвитку. 2013. № 1 (65). С. 122-126.

12. Друкер П.Ф. Бизнес и инновации. Киев: Вильямс, 2009. 423 с.

13. Вороновська М.М. Формування системи стимулів і мотивів інноваційної діяльності машинобудівних підприємств. Регіональна економіка. 2011.№ 2. C. 89-95. URL: http://nbuv.gov.ua/UJRN/regek_2011_2_12

14. Мочерний С.В. Економічна теорія. Київ: Академія, 2009. 640 с.

15. Стратегії інноваційного розвитку України на 2010-2020 рр. в умовах глобалізаційних викликів. URL: http://kno.rada.gov.ua/uploads/ documents/ 36382.pdf

16. Управління інноваційною складовою економічної безпеки : у 4 т. / за заг. ред. Прокопенко О. В., Школи В. Ю., Щербаченко В. О. - Суми: Триторія, 2017-. Т. 1: Теорія та методологія управління інноваційною складовою економічної безпеки / [Прокопенко О. В. та ін.], 2017. - 463 с. 
Економічні науки: збірник наукових праць Луцького начіонального технічного університету. Серія "Регіональна економіка". Випуск 18 (71). Редкол.: відп. ред. д.е.н., професор Л.Л. Ковальська. Луцьк: ІВВ Луцького НТУ, 2021. 278 с.

17. Федулова Л. І. Інноваційність розвитку сфери торгівлі. Вісник KHTEУ. 2016. №3. C.17-33. URL: http://visnik.knute.edu.ua/ index.php?option $=$ com_content $\&$ view $=$ article $\&$ id $=1790 \&$ catid $=192 \& l a n g=u k$

18. Пугачевська К.Й. Стратегічні напрями і тенденції інноваційного розвитку торгівлі. Науковий вісник Міжнародного гуманітарного університету. Серія: Економіка і менеджмент. 2015. Вип. 12. С. 58-60. URL: http://nbuv.gov.ua/UJRN/Nvmgu eim2015_12_14

19. Сайт Creatio Marketplace https://marketplace.terrasoft.ua/catalog\#/type /temp/category/all/certification/false/functional/25/cost/all/compatibility/all/all/new

20. Група компаній FOZZY GROUP. URL: http://www.fozzy.ua/ua

21. Прохорова В.В., Прохорова Ю.В., Кучеренко О.О. Управління економічною безпекою підприємств: монографія. Харків: УкрДАЗт, 2010. $282 \mathrm{c}$.

22. Функціональні стратегії інноваційного розвитку промислових підприємств: монографія / за наук. ред. В.В. Стадник. Хмельницький: ХНУ, 2016. $446 \mathrm{c}$.

\section{References}

1.Ghalushko Je.S. Pidvyshhennja efektyvnosti vykorystannja innovacijnogho potencialu $\mathrm{v}$ umovakh perekhodu do rynkovykh vidnosyn: avtoref. diss. ... kand. ekon. nauk: 08.06.02. Donecjk. 1999. 23p. [in Ukrainian]

2.Slepec Ju.S., Kostenko A.P. Ynnovacyonnuj potencyal kak эkonomycheskaja kateghoryja. Zbirnyk nauk. pracj NTU «KhPI». Kharkiv. 2001. Vyp.24. pp. 93-101. [in Ukrainian]

3. Isaksson R., Johansson P., Fischer K. Detecting Supply Chain Innovation Potential for Sustainable Development. Journal of Business Ethics (2010) 97:425-442 Springer, 2010. Available at: https://www.divaportal.org/smash/get/diva2:979822/ FULL TEXT01.pdf DOI 10.1007/s10551010-0516-z

4.Boghma O. S. Sutnistj innovacijnogho potencialu pidpryjemstva. Visnyk Zaporizjkogho nacionaljnogho universytetu. 2011. No 1(9). pp. 12-15. [in Ukrainian]

5. Gil N., Miozzo M., Massini S. The innovation potential of new infrastructure development: An empirical study of Heathrow airport's T5 project. Research Policy 41 (2012) 452-466. Available at: https://personalpages.manchester.ac.uk/ staff/nuno.gil/Journal\%20articles/RESPOL\%20Innovation\%20Potential.pdf

6.Gholovatjuk V.M. Investycijna pryvablyvistj innovacijnoji sfery ekonomiky Ukrajiny / za nauk. red. V.P. Solovjova. Kyjiv: Feniks, 2012. 364 p. [in Ukrainian]

7.Ryzhkov M.M., Makarenko Je.A., Piskorsjka Gh.A. Innovacijnyj potencial Ukrajiny v mizhnarodnykh vidnosynakh: monoghrafija. Kyjiv: Centr viljnoji presy, 2014. 283 p. [in Ukrainian] 
Економічні науки: збірник наукових праць Луцького начіонального технічного університету. Серія "Регіональна економіка". Випуск 18 (71). Редкол.: відп. ред. д.е.н., професор Л.Л. Ковальська. Луцьк: ІВВ Луцького НТУ, 2021. 278 с.

8. Nyzhnyk V.M. Innovacijne upravlinnja promyslovymy pidpryjemstvamy v systemi efektyvnogho vykorystannja konkurentnogho potencialu: monoghrafija / za nauk. red. V.M. Nyzhnyka. Khmeljnycjkyj: KhNU, 2014. 547 p. [in Ukrainian]

9. Rondi E., De Massis A., Kotlar J. Unlocking innovation potential: A typology of family business innovation postures and the critical role of the family system. Journal of Family Business Strategy, 10(4), 1-13. 2019. Available at: https://re.public.polimi.it/retrieve/handle/11311/1069328/478958/Rondi\%20et\%20al. Family\%20business\%20innovation\%20postures_Post-print.pdf

10. Mazaraki A., Meljnyk T. Innovaciji jak dzherelo strateghichnykh konkurentnykh perevagh. Visnyk KNTEU. 2010. No 2. pp. 5-17. [in Ukrainian]

11. P'jatnycjka Gh.T., P'jatnycjka, N.O. Vplyv innovacijnykh zmin na dijaljnistj pidpryjemstv restorannogho ghospodarstva. Ekonomika rozvytku. 2013. No 1 (65). pp. 122-126. [in Ukrainian] Ukrainian]

12. Druker P.F. Byznes y ynnovacyy. Kyev: Vyljjams, 2009. 423 p. [in

13. Voronovsjka M.M. Formuvannja systemy stymuliv i motyviv innovacijnoji dijaljnosti mashynobudivnykh pidpryjemstv. Reghionaljna ekonomika. 2011.No 2. Pp. 89-95. Available at: http://nbuv.gov.ua/UJRN/regek_2011_2_12 [in Ukrainian]

14. Mochernyj S.V. Ekonomichna teorija. Kyjiv: Akademija, 2009. 640 p.

15. Strateghiji innovacijnogho rozvytku Ukrajiny na 2010-2020 rr. v umovakh ghlobalizacijnykh vyklykiv. Available at: http://kno.rada.gov.ua/uploads/ documents/ 36382.pdf [in Ukrainian]

16. Upravlinnja innovacijnoju skladovoju ekonomichnoji bezpeky: u 4 Vol. / za zagh. red. Prokopenko O. V., Shkoly V. Ju., Shherbachenko V. O. — Sumy: Trytorija, 2017-. Vol. 1: Teorija ta metodologhija upravlinnja innovacijnoju skladovoju ekonomichnoji bezpeky / [Prokopenko O. V. ta in.], 2017. — 463 p. [in Ukrainian]

17. Fedulova L. I. Innovacijnistj rozvytku sfery torghivli. Visnyk KNTEU. 2016. No 3. pp.17-33. Available at: http://visnik.knute.edu.ua/index.php?option= com_content\&view=article\&id=1790\&catid=192\&lang=uk [in Ukrainian]

18. Pughachevsjka K.J. Strateghichni naprjamy i tendenciji innovacijnogho rozvytku torghivli. Naukovyj visnyk Mizhnarodnogho ghumanitarnogho universytetu. Serija: Ekonomika i menedzhment. 2015. No 12. pp. 58-60. [in Ukrainian]

19. Sait Creatio Marketplace https://marketplace.terrasoft.ua/catalog\#/type /temp/ category/all/certification/false/functional/25/cost/all/compatibility/all/all/new

20. Ghrupa kompanij FOZZY GROUP Available at: http://www.fozzy.ua/ua (accessed 20/09/2021) [in Ukrainian]

21. Prokhorova V.V., Prokhorova Ju.V., Kucherenko O.O. Upravlinnja ekonomichnoju bezpekoju pidpryjemstv: monoghrafija. Kharkiv: UkrDAZt, 2010. 282 p. [in Ukrainian]

22. Funkcionaljni strateghiji innovacijnogho rozvytku promyslovykh pidpryjemstv: monoghrafija / za nauk. red. V.V. Stadnyk. Khmeljnycjkyj: KhNU, 2016. 446 p. [in Ukrainian]

DOI: https://doi.org/10.36910/2707-6296-2021-18(71)-7 